\title{
Med middelalderen er det som med leverpostej...
}

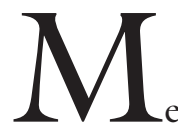

ed middelalderen er det som med leverpostej. Den findes i mange udgaver. Der er fransk og hjemmelavet, fedtfri og økologisk, ja sågar vegetarisk. Middelalderen findes som mørk og lys, romantisk, voldelig, som en nær eller fjern tid, interessant eller ganske uvedkommende. Der er frit valg eller er der? Ligesom enhver kundekreds får fat i den leverpostej, der passer den bedst, sådan skaber ethvert samfund sin eller sine forestillinger om middelalderen, tiden mellem oldtid og renæssance. Men der er naturligvis en forestilling om middelalderen, der er mere videnskabelig end andre, og det er vel den vi forskere skal arbejde på at udbrede? Ja, naturligvis. Den stadige fornyelse i forskningsmetoder, nyfund af tekster og andre spor af levet fortid, giver os stadig større og sikrere viden om en tabt tid. Tilbage står alligevel den situation, at vi altid farver vores opfattelse af fortiden med vor egen tids farver. Og fortiden kan aldrig genopstå selvom vi rekonstruerer byer og borge, dragter 
og mad, levevis og adfærd nok så energisk. Fortiden skabes i vort eget billede.Vi forstår bedst det vi genkender og har svært ved at forstå det anderledes.

Mange forskere, digtere og malere har gennem tiderne været fascinerede af middelalderen fordi den var vild, eksotisk, primitiv, romantisk, kompromisløs eller hvad man nu har syntes. For nogen har den stået som en guldalder, en tid, hvor mænd var mænd og kvinder kvinder, hvor det var til at se forskel på godt og ondt. Man idealiserede denne fjerne og tabte tid. Andre har brugt den som skræmmebillede. Man behandler $\mathrm{i}$ dag $\mathrm{i}$ visse lande forbrydere og sindssyge så barbarisk som var det i middelalderen, siger man. Kvindeundertrykkelsen er "ren middelalder"!

Hvilken slags middelalder man end opererer med, vil det være sådan, at opfattelsen af mænd og kvinder, af mandlighed og kvindelighed vil skifte med den generelle opfattelse af perioden. Og det er genstanden for de følgende sider, hvor jeg vil give et eksempel på, hvorledes man har "skabt sig" middelalderskikkelser, der ikke alene har fundet vej ind i en tids middelalderopfattelse, men hvad mere er, har været med til at præge denne tids egen opfattelse af det rette forhold mellem kønnene, af den rette mandlighed og kvindelighed. For sådan er det jo med historien. Vi forsker ikke i den og skriver ikke om den for fortidens skyld, men for at vi mennesker i dag kan blive rigere og klogere på os selv og vor egen tid.

Maleren Agnes Slott-Møller (1862-1936) skabte sine bedste, og muligvis sine kæreste værker inspireret af folkeviser og med emner hentet herfra. Fra lille pige holdt hun af verset om "Munken der går i enge den lange sommerdag" og plukkede blomster til sin hjertenskær, men dengang anede hun næppe hvad det var der i legen umiddelbart nåede hendes øre. Senere forstod hun, at det var folkevisens tone. Hun fortæller i sin biografiske skildring Folkevisebilleder fra
1923, hvordan hun endnu kan smelte, når hun hører folkevisernes strofer om sommeren: "Den sommer og den eng så godt kunne sammen", "Så faverlig ganger os den sommer". Hun skriver "Jeg stirrer folkevisebilleder frem af sommerens naturbilleder, landskabsbilleder.

\section{"Hr.Peder leger på sin forgyldene Harpe Det hørte fru Mette over Marke"}

I den lyse sommeraftenskumring sidder hr.Peder under det store lindetræ, hvis grene hænger helt ned til jorden, med sin harpe i hviden hænde, i græsset der gror højt op om ham, er der fuldt af de kniplingsfine skarntydeblomster, de fylder hele forgrunden op og ses som hvide slør langt ud over græsmark og eng. Det er en blikstille, hed sommeraften, vandet er som et spejl for den rødgrå, slørede himmel og for skovkystens mørke silhouet. Længst ude ses landet svinde hen i sommeraftenens blågrønne og rosalilla farver...".

Agnes Slott-Møllers middelalderbetagelse fandt udtryk både i folkevisebilleder og i mere historiske fremstillinger. Efter grundige faglige studier malede hun sin usædvanlige skildring af Margrethe d.1, senere et portræt af Oluf og et af Niels Ebbesen. Men historiemaleriet mødte kritik og hun mødte nok mere anerkendelse for sine folkevisebilleder. Som de fleste i sin samtid regnede hun viserne for middelalderlige og diskuterede ikke som i dag visernes oprindelse og eventuelt meget senere datering. For hende afspejlede de et samlet univers, det xgte danske, og hun oplevede i mødet med denne middelalderdigtning et udtryk for de store, evige følelser.

Med sine billeder fortalte Agnes SlottMøller visernes historier, skildrede centrale scener fra handlingen. Hun arbejdede både med de såkaldte historiske viser som den om Dronning Dagmars død, og med de mere digteriske som Ebbe Skammelsen visen, Agnete og havmanden, Jomfru Blidelil etc. De fleste af hendes malerier og relieffer 


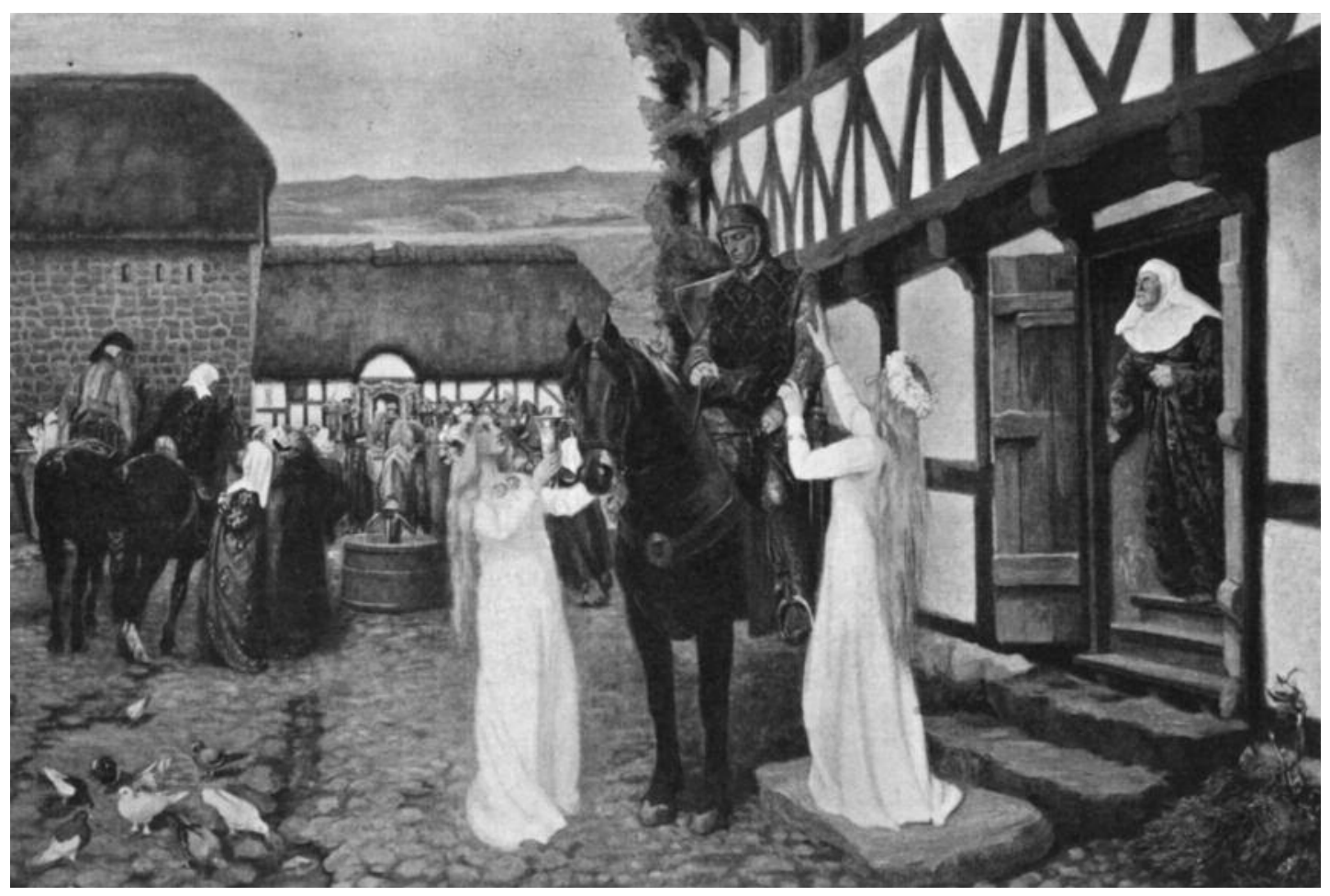

Agnes Slott Moller: "Ebbe Skammelsen i Bryllupsgairden" 
rummer kvindeskikkelser, der selvfølgeligt gror ud af hendes forestillinger om visernes middelalderunivers. Romantisk, dramatisk. Klare farver, klare værdier med sort og hvidt, godt og ondt og alt præget af det tungsind, der for hende var den særlige nordiske tone.

For maleren og forfatteren Agnes SlottMøller var dette at fortælle Danmarkshistorie det væsentligste. At fremstille, så tro og nøjagtigt som muligt den verden hun læste og følte sig til gennem studiet af historien og især den middelalderlige billedverden, her i Danmark og i den kristne middelalders kunstvugge: Italien. På rejser til Sydeuropa havde hun sammen med sin mand, maleren Harald Slott-Møller tidligt oplevet de gamle mestre, i kirker og på museer, og det var i 1200 til 1400-tallets kunst de begge fandt deres store forbilleder, ikke mindst Carpaccio. Fælles for disse gamle kunstnere var den enkle malemåde, de klare farver, den tro gengivelse af natur og ting, alt med den hensigt at lade kunsten tjene et højere mål. Harald S-M udtrykker det i Kunstens Kilder fra 1917. "I den oldgræske tid var kunstneren organ for fædrelandskærligheden, i den kristne middelalder blev kunstudøvelsen Gudsdyrkelse”. Naturen og menneskets sjæl er kunstens uudtømmelige kilder og evighedslængslen det kendetegnende.

Agnes ønskede som kunstner "troværdigt at uddybe, udforme og befæste Danmarksbilledet i sit folks bevidsthed". (158). Og det Danmarksbillede hun skabte for sig selv og andre hentede hun frem gennem sin oplevelse af folkevisens Danmark, "det ældste billede af vort fædreland vi ejer". Samtidig var hun sig kunstens forløsende evne bevidst. Smukkest udtrykt i hendes billede af pigen ved væven, der under sit arbejde synger den gamle vise. Skjult i mørket bag hende står Ebbe Skammelsen, som et gammelt, gråt genfærd, der lytter til hendes sang, sangen om ham selv og hans ugerning, og herigennem bliver han ifølge sagnet fri og kan dø. Når han hørte sin egen vise synge, ville det ske. Når livets hændelser bliver til poesi kan mennesket forløses.

Opfattelsen af, at historien, især folkets og fædrelandets, var afgørende i opdragelsen af børn og unge, var almindelig i 1890'ernes Danmark efter tabet af Sønderjylland og Slesvig. Agnes var en af de glødende patrioter, og havde også den dybere forståelse af historien som grundlaget for menneskelivet i det hele taget. Grundtvigs indflydelse rakte vidt og bredte sig over både by og land. Det synes ganske selvfølgeligt at det var Agnes Slott-Møllers relief, en trefløjet fortælling om Dagmars død man ser hænge på væggen over talerstolen på Askov højskole på det berømte billede herfra malet af Erik Henningsen i 1902. Forstander Ludvig Schrøders fortælling om Danmarkshistorien og dens kvindeskikkelser har sikkert kunnet spille sammen med Agnes Slott-Møllers kunstneriske fortolkning. Netop i 1902 var mine bedsteforældre på højskole, den ene på Askov, den anden på Vallekilde, og gennem deres korrespondance fra dette år fik jeg for nylig bekræftet den påvirkning højskolen øvede på de unge. Fædrelandets krav, glæden over at være dansk, danskhedens dybe sammenhæng med kristendom, med centrale værdier som hjem, xgteskab og børn. Mine bedsteforældre lyttede med glæde til oplysning om kønnenes komplementaritet, at de var som to halvkugler der skulle passe sammen. De to køns forskellighed og dermed forskellige opgaver blev forkyndt på mange måder, også i foredrag om middelalderns store skikkelser: dronningerne Thyra, Dagmar og Margrethe og de fandt udtryk i de sange, der hørte med til højskolelivet. Man sang både de gamle folkeviser i gendigtninger eller i pasticher som Henrik Hertz' digt om Dronning Dagmar, der kom "Fra fjerne lande..". Netop denne sang understreger 1800-tallets opfattelse af den blide, rene, elskelige unge prinsesse, der vinder alles hjerter, også kong Valdemars, med sin skønhed, medfølelse og godhed. 


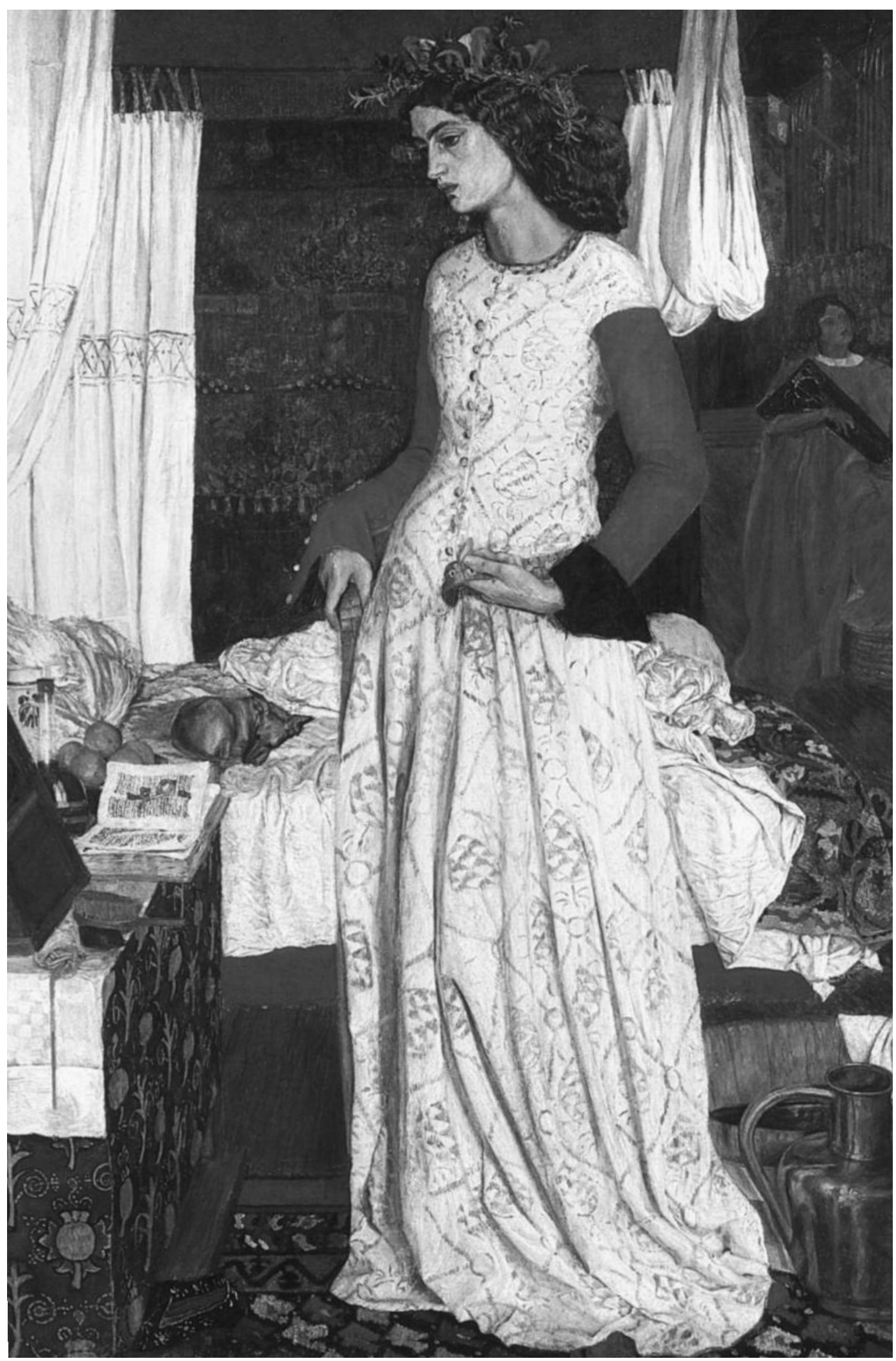

William Morris: "Den smukke Isolde", 1858 
Som kunstner var Agnes Slott-Møller en oprører. Sammen med sin mand nægtede hun at bøje sig for tidens krav, nemlig at tage den fransk impressionistiske malerkunst som forbillede. Hun fandt derimod åndsfrænder og inspiration hos de engelske præraphaelitter, hvis malerier og tegninger hun så under et Englandsophold i 1898. Ligesom hun hentede disse malere deres inspiration primært hos middelalderens kunstnere, fra tiden før Raphael. De berømteste i den engelske gruppe, det prærafaelitiske broderskab, dannet 1848, var Holman Hunt, Millais og D.G.Rosetti. På Agnes Slott-Møller's tid havde de dannet skole og hun kunne glæde sig også over deres efterfølgere W.Morris og ikke mindst E. BurneJones. Hos Burne-Jones oplevede Agnes eventyrfortælleren, fortrylleren, regnbuemageren. De engelske malere havde inspireret af Keats og Tennyson hentet deres motiver og emner i middelalderens sagn og legender: Tristan og Isolde, Dante og Beatrice, Skt.Georg og dragen etc. Karakteristisk for deres malemåde - som Slott-Møllers i høj grad dyrkede - var den vægt der lå på det maleriske, dekorative. Med stor naturtroskab gengav man interieurer med genstande og inventar. Isolde står i sit kammer i en kjole, hvis stoflighed er betagende, sengeklæder, tæpper, gardiner, håndarbejder, bønnebøger med fine, små miniatureilluminationer, ja alt er gengivet med en farverig stoflighed, der understreger den skønhedsoplevelse af situationen, som helst skal forhøje det følelses- og bevidsthedsmæssige indtryk. Middelaldermennesket bliver virkeligt!

De kvindeskikkelser vi finder hos de engelske malere er også skabt ud fra et komplementaritetssyn. Kvinderne opbygger med deres tro, mod og underdanighed den virile mandighed. Som personer er de ofte damer hentet fra den høviske verden. De idealiseres og sættes på piedestal i billederne. De to modsatrettede aspekter af kvindeligheden, seksualiteten og helligheden, findes i billederne: Kvinden på den ene side som begæret og kysk, som from, pligtopfyldende ungmø og på den anden som forførende heks. Dette billede svarede ifølge kunsthistorikeren Jan Marsh til Victoriatidens kvindeopfattelse, og hvad mere var, denne fortidskonstruktion virkede ind på samtiden. Måske både bevarende og frigørende? Jeg forestiller mig, at netop denne romantiske, xstetiserende fremstilling af kvinder baåde har kunnet påvirke dem til at hengive sig til denne skønne livsstil i drømmen om ridderen på den hvide hest, og samtidig har den måske kunnet provokere et opgør frem hos dem, der ikke kunne nøjes med at vente! Billedet af den fangne kvinde, der venter på ridderen, der kan befri hende, var populært ligesom den indespærrede kvinde, ofte i skikkelse af "The lady of Shalott" fra Tennyson's digt. Over denne frue hviler den forbandelse, at hun dør hvis hun forlader borgen Camelot. Rækken af billeder, der viser kvinder som "The lady of Shalott", der ser ud i et sollyst landskab, fanget i et gyldent bur, tolkes af Jan Marsh som symbol på Victoriatidens kvindelighed. Begrænset, indespærret af kønnet, og med bevidstheden om at udbrud af denne "naturlige" tilstand for at opnå frihed betød døden, om ikke den virkelige så den sociale.

Var Agnes Slott-Møllers folkevise- og middelalderskikkelser også billeder af hendes tids kvindelighed? Det er umiddelbart svært at svare på. Agnes S-M var selv en selvstændig, veluddannet udøvende kunstner, anerkendt omend ikke i den målestok hun mente, hun fortjente det. Hun var aktiv i kvindesagen på forskellige måder, deltog bl.a. i Kvindernes udstilling i 1895 og var formand for Danske kvinders Forsvarsforening fra 1915 til 1917. I sin professionelle bane tog hun sammen med sin mand et brud med den etablerede kunstverden ved at medvirke til stiftelsen af Den frie Udstilling i 1891. Ægteparret Slott-Møller begyndte som radikale, venner med Georg Brandes, og endte som højreorienterede, i hvert fald $\mathrm{i}$ andres øjne. Agnes reflekterer i 
Folkevisebilleder over det moderne og dets udspring. Hun vender sig mod tolkningen af det franske som det moderne og føler sig ligesom sine engelske forbilleder mere i slægt med den ældste fortid, middelalderen, fremfor den så højt beundrede renæssance. De kvinder Agnes Slott-Møller vælger at give liv i sine billeder er de fine, gode hustruer og møer. Ikke sensuelle, dæmoniske skikkelser med stor erotisk udstråling som i den engelske billedverden. Kvinderne skildres ikke som undertrykte, men nok som prisgivet mænd og allermest skæbnen. Men de møder oftest livets tilskikkelser med ro, tålmod og styrke. Ved at dyrke folkevisens Danmarksbillede sætter Agnes Slott-Møller ovennævnte kvindetyper i centrum og ved at gøre middelalderens univers til det oprindelige, ægte danske gør hun også disse kvinder med deres skønne, blide væsen til een naturlig, evig kvindelighed. Det ligger i sagens natur.

I sin korrespondance med kollegaen Marie Krøyer, i breve som ikke er gennemredigerede for et alment publikum, giver Agnes ikke indtryk af at have mødt modstand på grund af sit køn. Det var snarere hendes malemåde, der vakte modstand og kritik. Den rettedes mod den tomhed og stivhed begge ægtefællers billeder kunne få præg af fordi der lå så megen vægt på det dekorative.

Et ubesvaret spørgsmål til slut: Var Agnes Slott-Møller med sine billeder med til at fastholde kvinder i et samfund, der begrænsede dem som i samtidens England? Gik billederne ind i kvinders og mænds indlevelse i Danmarkshistorien, og medvirkede til en historisk-poetisk, en kunstnerisk forløsning af evigt menneskelige spørgsmål? Eller blev hendes værker opfattet som ren xstetik, dekorative og uvedkommende? Var det netop fordi de var intetsigende, at hun ikke fik de store officielle opgaver hun ønskede sig? Agnes Slott-Møller fik hos kvinder stor anerkendelse bl.a. diverse legater, og hendes billeder blev givet som gaver til estimerede institutioner, hvor de blev ophængt. Jeg tror afgjort billederne var væsentlige faktorer i tidens fortolkning af middelalderen og fik den virkning malereren drømte om.

Jeg har fået lyst til at forske mere i, hvor bevidst Agnes Slott-Møller var om det kvindebillede hun formidlede og den virkning det kunne have på tidens kvindespørgsmål. Måske levede hun med en dobbelt forestilling om kvindelighed med en romantisk drømmeside og en mere kontant hverdagsside? Og henlagde måske ubevidst den romantiske side af den til en svunden fortid uden at reflektere over dennes indvirken på hendes egen samtid, selvom middelalderen jo netop var levende og betydningsfuld for hele hendes livssyn? Selv begavede og velformulerede mennesker behøver ikke at have helt styr på deres forestillinger. Har nutidens meget kønsbevidste og selvstændige kvinder ikke tit en drøm om at være prinsesser, klædt på til at blive erobret, en drøm om at være fruer i et skønt hjem etc.? Ugebladenes reportager og tidens mode tyder på det. Præ-rafaelitternes bedårende billeder af middelalderlige interiører kan også få en feminist anno 1997 til at falde i trance over denne overflod af vidunderlig, rig tekstilkunst, fremstillet som båret, skabt og valgt af middelalderens kvinder. Men hvorfor skulle en feminist også give afkald på glæden over skønhed?

Til slut tilbage til middelalderen, forhåbentlig med en forhøjet bevidsthed hos min læser om, at denne periode ikke blot befinder sig i en fjern fortid, men at den er noget der bliver til netop nu! Derfor kan jeg spørge: Hvilken middelalder ønsker vi kvindehistorikere at frembringe? Som forskere naturligvis en der forandres i takt med nye fund, nye forskningsresultater, fremfor alt en der farves af vores syn på kønnets karakter og betydning. Derfor bliver vores middelalder anderledes end den romanti- 
ske. En nemt iagttagelig forskel bliver, at den befolkes med mennesker, ikke kun med mænd, der på overfladen behersker det patriarkalske samfund, men med kvinder, der lever og udfolder sig indenfor disse rammer, til hverdag og fest, på samfundets top og bund. Betydelige skikkelser har i de sidste årtier fået stadig skarpere konturer, mere facetterede ansigter. Vi kender nu bedre middelalderlige kvindelige teologer, mystikere men også kvinder i forskellige erhverv. Vores middelalder er et alternativ til den romantiske, nordiske folkeviseverden, som netop beskrevet. Den er snarere præget af opfattelsen af en dansk fortid, som del af en europæisk kultur, selvom mødet mellem det nordiske og det mere kontinentale stadig må opfattes som et dynamisk felt, ikke mindst i disse EU-tider. Vores ny middelalder, præget af kvindeliv og af kvinde- og kønsforskning er som en ny type leverpo- stej: vitaminrig, broget, kraftig, et uomgængeligt tilbud på ethvert ordentligt frokostbord.

\section{LITTERATUR}

- Agnes Slott-Møller, 1923, Folkevisebilleder, København

- Harald Slott-Møller,1917, Kunstens Kilder,

Købehavn

- Bodil Busk Laursen o.a., Red., 1988, Kunst og

Idealer, Kunstforeningen

- Agnes og Marie. Breve mellem Agnes Slott-Møller

og Marie Kroyer 1885-1937. Ved Lise Svanholm. Gyldendal 1991.

- Jan Marsh, 1987, Pre-raphaelite Women, London

Nanna Damsholt

Docent, dr.phil,

Center for Kvinde- og Kønsforskning

Københavns Universitet 